\title{
GUGATAN GANTI KERUGIAN DALAM KASUS PENCEMARAN NAMA BAIK MENURUT KITAB UNDANG-UNDANG HUKUM PERDATA
}

\author{
I Made Heriyana, Anak Agung Sagung Laksmi Dewi, Ni Made Puspasutari Ujianti \\ Fakultas Hukum Universitas Warmadewa, Denpasar - Bali, Indonesia
}

\begin{abstract}
Abstrak
Perlindungan hukum terhadap korban pencemaran nama baik dalam sistem hukum nasional belum memperoleh perlindungan yang memadai. Padahal dalam konsep negara hukum selayaknya wujud perlindungan terhadap korban kejahatan harus mendapatkan porsi yang besar sebagai bentuk perlindungan negara terhadap masyarakat. Penelitian ini bertujuan untuk mengetahui gugatan ganti kerugian yang dilakukan korban pencemaran nama baik berdasarkan KUH Perdata dan proses ganti kerugian terhadap korban pencemaran nama baik. Mengacu pada tujuan penelitian maka tipe penelitian yang digunakan adalah penelitian normatif. Metode yang digunakan dalam pengolahan bahan hukum yaitu metode analisis data deskriptif analitis. Penggantian kerugian yang ditimbulkan atas pencemaran nama baik di atur dalam KUHPerdata Pasal 1372-1380 sebagai bentuk perbuatan melanggar hukum sebagaimana diatur dalam Pasal 1365 KUHPerdata. Ada tempo kadaluwarsa untuk mengajukan gugatan ganti rugi karena penghinaan yaitu gugatan harus diajukan dalam tempo satu tahun sejak hari dilakukannya perbuatan dan diketahuinya perbuatan/penghinaan itu oleh penggugat. Ganti rugi dimaksudkan untuk memulihkan keadaan korban agar ia berada dalam atau kembali pada keadaan seperti seandainya tidak ada penghinaan dengan kata lain dimaksudkan untuk menggantikan yang hilang atau berkurang dari korban penghinaan.
\end{abstract}

Kata Kunci: Gugatan Ganti Kerugian; KUHP; Pencemaran Nama Baik

\begin{abstract}
Legal protection for victims of defamation in the national legal system has not received adequate protection. Whereas in the concept of the rule of law, the form of protection for victims of crime must obtain a large portion as a form of state protection for the community. This study aims to determine the claim for compensation made by victims of defamation based on the Civil Code and the process of compensation against victims of defamation. Referring to the research objectives, the type of research used is normative research. The method used in processing legal material is descriptive analytical data analysis method. The compensation resulting from defamation is regulated in the Civil Code Article 1372-1380 as a form of unlawful acts as regulated in Article 1365 of the Civil Code. There is an expiry time for filing a claim for compensation due to an insult that is the suit must be filed within one year from the day the act was carried out and the plaintiff knew the act / insult. Compensation is intended to restore the victim's condition so that he is in or return to the state as if there were no insults in other words intended to replace the lost or reduced victims of insults.
\end{abstract}

Keywords: Criminal Code; Defamation; Lawsuit for Compensation

\section{PENDAHULUAN}

Saat ini perkembangan bentuk kejahatan jenis pencemaran nama baik terus saja meningkat termasuk dengan adanya perkembangan teknologi yang mana menyebabkan kejahatan tersebut semakin saja meningkat (Anggara 2016). Dilihat dari Kitab Undang-Undang Hukum Pidana (selanjutnya disebut KUHP) pencemaran nama baik diistilahkan sebagai penghinaan atau penistaan terhadap seseorang (Soesilo 1995).

Saat ini sangat banyak diberitakan di media-media mengenai bentuk pidana pencemaran nama baik oleh berbagai orang. Hal tersebut dilatarbelakangi oleh berbagai macam hal seperti pembuatan email dan meneruskan e-mail pelaporan tindak pidana korupsi, menyiarkan berita atau peristiwa melalui media sosial, menyampaikan hasil penelitian dan beberapa hal lainnya. Melihat penyebab-penyebab 
tersebut tentunya cukup mengkhawatirkan masyarakat. Bentuk tindak pidana penghinaan dapat menimbulkan kerugian yang tentunya bukan saja materiil namun juga non-materiil.

Macam-macam kerugian yang bisa saja diderita oleh korban penghinaan tidak saja dalam bentuk fisik namun juga berkaitan dengan biaya-biaya yang dibutuhkan guna menyembuhkan luka fisik tersebut dan adanya kemungkinan hilangnya kepercayaan banyak pihak yang mempengaruhi pendapatan korban dalam pekerjaan dan bukan saja materiil kerugian juga dapat berupa non-materiil yang tidak dapat dinilai dengan materi atau uang (Lamintang 1997). Tidak seimbangnya jiwa yang dikarenakan hilangnya semangat untuk hidup dan kepercayaan dari orang lainnya yang menimbulkan ketakutan dan kecemasan akan bayang-bayang bentuk tindak pidana yang menghantui korban yaitu salah satunya bentuk kerugian non-fisik yang timbul akibatnya (Djojodierdjo 2009).

Setiap warga negara yang mana hak keperdataannya dilanggar oleh individu lainnya dapat mempergunakan haknya untuk menggugat orang tersebut ke Pengadilan Negeri setempat dengan bentuk tuntutan ganti kerugian. Tuntutan hak yang dilakukan berupa gugatan perbuatan melawan hukum sebagaimana diatur dalam ketentuan pasal 1365 KUHperdata. Hak untuk melakukan ganti kerugian atas perbuatan penghinaan yang dilakukan pelaku diatur dalam ketentuan pasal 1372 KUHPerdata (Setiawan 2007). Selain itu, harus diperhatikan mengenai kerugian yang bersifat materiil atau non-materiil. Dengan adanya penggantian kerugian yang memiliki sifat materiil tidak banyak menimbulkan masalah tidak saja demikian akibat kerugian non-materiil yang bisa berupa kecemasan kesusahan rasa malu dan lainnya (Suparman 2007).

Bentuk perlindungan yang diberikan oleh negara kepada rakyat namun dalam implementasinya, adanya kesan bahwa korban masih sering disampingkan dalam pencarian keadilan. Restitusi yaitu bentuk perbaikan atas kerugian yang diterima

korban dari pelaku baik kerugian fisik moril maupun materiil kedudukan atau jabatan serta hak-hak lainnya (Sapardjaja 2012).

Berkaitan dengan latar belakang yang telah diuraikan maka dapat dirumuskan beberapa permasalahan, yaitu bagaimanakah gugatan ganti kerugian yang dilakukan korban pencemaran nama baik berdasarkan KUHPerdata? Dan bagaimanakah proses ganti kerugian terhadap korban pencemaran nama baik? Adapun tujuan penelitian ini yang didasarkan atas rumusan masalah yaitu untuk mengetahui gugatan ganti kerugian yang dilakukan korban pencemaran nama baik berdasarkan KUHPerdata dan proses rehabilitasi terhadap korban pencemaran nama baik.

\section{METODE PENELITIAN}

Jenis penelitian yang dilakukan adalah jenis penelitian hukum normatif. Penelitian hukum normatif didasarkan kepada penelitian kepustakaan atau dengan menggunakan bahan hukum sekunder lainnya (Soekanto and Mamudji 1995). Dalam melakukan penelitian hukum normatif, bahan hukum yang digunakan yaitu bahan hukum primer, bahan hukum sekunder, dan bahan hukum tersier.

Bahan hukum primer terdiri dari perundang-undangan catatan resmi atau risalah dalam pembuatan perundang-undangan dan putusan-putusan hakim yang telah mendapatkan keputusan hukum tetap. Bahan hukum sekunder yaitu bahan yang dikumpulkan dengan referensi buku teks bahan hukum lainnya yang dalamnya mengandung pandangan- pandangan hukum apra yuris. Penggunaan bahan hukum sekunder dalam penelitian ini mempergunakan buku dan jurnal hukum serta lain sebagainya yang berkaitan dengan isu hukum yang diteliti (Sedarmayanti and Hidayat 2002). Bahan hukum tersier adalah bahan hukum yang dipergunakan dengan mempelajari kamus hukum ensiklopedia dan bahan hukum tersier lainnya. Dalam penelitian ini bahan hukum tersier yang dipergunakan yaitu Kamus Besar Bahasa Indonesia Kamus Hukum dan media lainnya yang berkaitan dengan isu hukum yang diteliti.

Teknik pengumpulan bahan hukum yang digunakan dalam penelitian ini yaitu teknik studi dokumen dipergunakan untuk melakukan bentuk catatan terhadap sumber bahan hukum primer dan bahan hukum sekunder yang selanjutnya dilakukan dalam menyelesaikan permasalahan yang berkaitan dengan isu hukum yang dibahas, studi Kepustakaan merupakan teknik yang dipergunakan guna menemukan data mempergunakan penelaah terhadap catatan buku yang berkaitan dan berhubungan dengan isu hukum yang akan diteliti, dan studi Internet suatu teknik yang dipergunakan dengan mengumpulkan bahan atau data yang dicar dengan pertanyaan- pertanyaan atau kata-kata yang berkaitan dengan isu hukum di internet. 
Metode yang digunakan dalam pengolahan bahan hukum yaitu metode analisis dengan bahan hukum yang dideskripsikan mengacu pada masalah yang diteliti serta dikaitkan dengan doktrin-doktrin hukum yang berdasarkan ketentuan peraturan perundang-undangan. Penggunaan analisis deskriptif adalah dengan memberikan suatu gambaran yang komprehensif dan juga sistematis terhadap isu hukum yang diteliti.

\section{HASIL DAN PEMBAHASAN}

\section{Gugatan Ganti Kerugian yang Dilakukan Korban Pencemaran Nama Baik Berdasarkan KUHPerdata}

Tindak pencemaran nama baik adalah salah satu dari kejahatan khusus dari perbuatan melawan hukum dalam keperdataan. Istilah yang dipergunakan mengenai bentuk dari perbuatan melawan hukun ini yaitu dengan pencemaran nama baik. Pada prinsipnya yang dipergunakan sebagai ukuran atau indikator mengenai pencemaran nama baik seseorang masihlah belum jelas dan terang diatur dalam ketentuan hukum pidana bahkan perdata hal tersebut karena pencemaran nama baik sangat subjektif dan banyak faktor yang harus diuraikan kembali. Dalam pencemaran nama baik yang diberikan perlindungan yaitu kewajiban seseorang yang dihormati oleh orang lain dari pandangan kehormatan tersebut maka nama baik dimata seseorang adalah bentuk dari kejahatan yang berat.

Bentuk pencemaran nama baik atau penghinaan yang disiarkan baik secara tertulis dikenal dengan nama libel dan penghinaan yang diucapkan dikenal dengan slander. Bentuk penghinaan yang dibagi menjadi 5 (lima) kategori yakni pencemaran tertulis pencemaran penghinaan ringan fitnah fitnah tuduhan dan fitnah pengaduan. Prinsip perbuatan penghinaan yaitu menyerang korban dengan melukai kehormatan dan/atau nama baiknya golongan agama lembaga dan termasuk pula orang yang telah meninggal (Agustina 2003). Umumnya bentuk penghinaan masuk sebagai kasus delik aduan. Seseorang yang dihina bisa saja melakukan gugatan ke Pengadilan Negeri untuk menuntut kerugian dan mendapatkan ganti rugi.

Tindak pidana terhadap kehormatan atau penghinaan atau pencemaran nama baik selain diatur dalam KUHP juga disinggung dalam UU ITE mengenai media pencemaran nama baik. Tetapi bentuk penggantian yang dilakukan kerugian yang timbul dari kejahatan pencemaran nama baik dalam ketentuan hukum perdata diatur dalam Pasal 1372-1380 KUHPerdata yang selanjutnya dapat digabungkan dengan bentuk perbuatan melawan hukum Pasal 1365 KUHPerdata.

Dalam konstruksi Pasal 1376 KUHPerdata memang ada pernyataan yang bersifat menghina tetapi oleh undang-undang maksud untuk menghina dianggap tidak ada kalau pernyataan yang bersifat menghina itu dimaksudkan untuk melindungi kepentingan umum atau untuk bela diri. Padahal untuk berhasilnya gugat perdata berdasarkan Pasal 1372 KUHPerdata harus dibuktikan adanya maksud untuk menghina. Dengan demikian orang yang memberikan pernyataan yang isinya objektif bersifat menghina orang lain dapat membebaskan diri dari tuntutan kalau pemberitaan itu dimaksudkan untuk mengingatkan kepada masyarakat akan adanya peristiwa yang merugikan masyarakat atau mengingatkan anggota masyarakat akan adanya bahaya yang mengancam kepentingan mereka.

\section{Ganti Kerugian terhadap Korban Pencemaran Nama Baik}

Kasus Ganti kerugian terdapat dalam hukum perdata dan pidana. Namun antara keduanya memiliki perbedaan. Ketentuan dalam wilayah hukum pidana bentuk pemberian ganti kerugian lebih sempit daripada pemberian ganti kerugian dalam wilayah hukum perdata. Mengenai hal tersebut ganti kerugian dalam ranah perdata memang lebih luas dari pada ranah hukum pidana. Hal tersebut diakibatkan karena ganti kerugian dalam ranah hukum perdata (Pasal 1365 KUHPerdata) yaitu pengembalian kondisi dalam keadaan semula sebagaimana sebelum timbulnya kerugian. Dalam hukum perdata ganti kerugian bisa dimintakan setinggi tingginya (tidak ada jumlah minimum dan maksimum) mencakup kerugian materil dan kerugian immaterial.

Berdasarkan Pasal 1372 KUH Perdata tuntutan perdata tentang penghinaan bertujuan untuk mendapatkan penggantian kerugian serta pemulihan

kehormatan dan nama baik. Walaupun di dalam KUHPerdata terdapat ketentuan mengenai tuntutan ganti kerugian tetapi tidak terdapat patokan yang dapat digunakan untuk mengukur apa yang dinamakan ganti rugi apa unsur-unsurnya dan besarnya ganti rugi sehingga orang biasanya akan 
menerapkan secara analogi ketentuan ganti rugi yang ada dalam Bab I dari Buku III KUHPerdata tersebut.

Masyarakat membedakan kerugian menjadi kerugian materiil dan kerugian immateriil (moril). Kerugian materiil adalah kerugian-kerugian yang bisa dinilai dalam sejumlah uang tertentu sedangkan kerugian immateriil (atau moril) adalah kerugian-kerugian yang tidak bisa dinilai dengan sejumlah uang tertentu. Pada umumnya orang menerima bahwa yang dinamakan ganti kerugian adalah ganti rugi dalam wujud sejumlah uang walaupun kerugian yang dirasakan merupakan kerugian immateriil (moril) yang tidak ada kaitannya dengan kekayaan korban.

\section{SIMPULAN DAN SARAN}

\section{Simpulan}

Berdasarkan uraian-uraian di atas dapat ditarik kesimpulan bahwa gugatan ganti kerugian yang dilakukan korban pencemaran nama baik berdasarkan KUHPerdata diatur dalam KUHPerdata Pasal 1372-1380 KUHPerdata. Tindak pencemaran nama baik adalah salah satu dari kejahatan khusus dari perbuatan melawan hukum dalam keperdataan. Istilah yang dipergunakan mengenai bentuk dari perbuatan melawan hukun ini yaitu dengan pencemaan nama baik. Pada prinsipnya yang dipergunakan sebagai ukuran atau indikator mengenai pencemaran nama baik seseorang masihlah belum jelas dan terang diatur dalam ketentuan hukum pidana bahkan perdata hal tersebut karena pencemaran nama baik sangat subjektif dan banyak faktor yang harus diuraikan kembali. Dalam pencemaran nama baik yang diberikan perlindungan yaitu kewajiban seseorang yang dihormati oleh orang lain dari pandangan kehormatan tersebut maka nama baik dimata seseorang adalah bentuk dari kejahatan yang berat

Proses ganti kerugian terhadap korban pencemaran nama baik diselesaikan melalui jalur perkara perdata di pengadilan yang telah diatur dalam hukum acara perdata. Kasus Ganti kerugian terdapat dalam hukum perdata dan pidana. Namun antara keduanya memiliki perbedaan. Ketentuan dalam wilayah hukum pidana bentuk pemberian ganti kerugian lebih sempit daripada pemberian ganti kerugian dalam wilayah hukum perdata. Mengenai hal tersbut ganti kerugian dalam ranah perdata memang lebih luas dari pada ranah hukum pidana. Mengenai penyelesaian yang lebih baik ditempuh oleh pihak-pihak yang berperkara adalah melalui bentuk penyelesaian non-litigasi yang didasarkan akan asas musyawarah mufakat. Selain itu dalam proses penyelesaian melalui non-litigasi lebih singkat dan tidak memerlukan biaya yang banyak dan dapat memperbaiki kembali hubungan-hubungan antara para pihak.

\section{Saran}

Adapun saran yang dapat diberikan berdasarkan pembahasan di atas adalah pemerintah selaku regulator harus dapat mengkonkritkan kembali mengenai tindak pidana pencemaran nama baik atau penghinaan hal ini penting agar terdapat pemahaman yang jelas mengenai unsur-unsur penghinaan atau pencemaran nama baik tersebut. Hal ini juga akan mempermudah apabila ada masyarakat untuk mengajukan gugatan ganti kerugian berkaitan dengan penghinaan atau pencemaran nama baik.

Masyarakat agar dapat lebih bijaksana dalam menyampaikan pendapat atau menyampaikan hal lainnya mengingat banyak sekali kasus penghinaan atau pencemaran nama baik yang berakhir di jalur pidana. Sehingga jalur perdata melalui gugatan ganti kerugian merupakan solusi yang dapat ditempuh apalagi jika dapat diselesaikan secara win-win solution.

\section{DAFTAR PUSTAKA}

Agustina, Rosa. 2003. Perbuatan Melawan Hukum. Jakarta: Pasca Sarjana FH Universitas Indonesia. Anggara, Komarudin. 2016. Menimbang Ulang Pasal 27 Ayat 3 UU ITE Dalam Putusan Pengadilan. Jakarta: Institute For Criminal Justice Reform.

Djojodierdjo, MA Moegni. 2009. Perbuatan Melawan Hukum. Jakarta: Pradnya Paramita.

Lamintang, P. A. F. 1997. Dasar-Dasar Hukum Pidana Indonesia. Jakarta: Citra Aditya Bakti. Sapardjaja, Komariah Emong. 2012. Ajaran Sifat Melawan Hukum Material Dalam Hukum Pidana Indonesia. Bandung: Alumni.

Sedarmayanti and Syarifuddin Hidayat. 2002. Metodelogi Penelitian. Bandung: Mandar Maju. Setiawan, Rachmat. 2007. Tinjauan Elementer Perbuatan Melawan Hukum. Bandung: Alumni. Soekanto, Soerjono and Sri Mamudji. 1995. Penelitian Hukum Normatif Suatu Tinjauan Singkat. Jakarta: Rajawali Pers.

Soesilo, R. 1995. Kitab Undang-Undang Hukum Pidana (KUHP) Serta Komentar- Komentarnya 
Lengkap Pasal Demi Pasal. Bogor: Politeia.

Suparman. 2007. "Kepentingan Korban Tindak Pidana Dilihat Dari Sudut Viktimologi." Majalah Hukum FH-UI Tahun Ke-XXII No. 260 Juli 2007. 